Winter 2008

\title{
Privatization and Public Law Values: A View from France
}

Manuel Tirard

University of Paris X-Nanterre

Follow this and additional works at: https://www.repository.law.indiana.edu/ijgls

Part of the Civil Law Commons, Comparative and Foreign Law Commons, and the International Law Commons

\section{Recommended Citation}

Tirard, Manuel (2008) "Privatization and Public Law Values: A View from France," Indiana Journal of Global Legal Studies: Vol. 15 : Iss. 1 , Article 12.

Available at: https://www.repository.law.indiana.edu/ijgls/vol15/iss1/12

This Symposium is brought to you for free and open access by the Law School Journals at Digital Repository @ Maurer Law. It has been accepted for inclusion in Indiana Journal of Global Legal Studies by an authorized editor of Digital Repository @ Maurer Law. For more information, please contact rvaughan@indiana.edu.

\section{$\Psi$}

JEROME HALL LAW LIBRARY

$$
\begin{aligned}
& \text { INDIANA UNIVERSITY } \\
& \text { Maurer School of Law }
\end{aligned}
$$




\title{
Privatization and Public Law Values: \\ A View from France
}

\author{
Manuel Tirard*
}

Abstract

This article uses a comparative approach to explore privatization and its consequences on public law values. It discusses the French model for protecting these values, which limits the scope of privatization and applies a legal regime within which public law norms play an active role. While it does not suggest that this model can or should be applied in the United States, it does express that the French experience can enrich American debates on the subject.

\section{INTRODUCTION}

As Paul Seidenstat noted a few years ago, " $[t]$ he role of government in the marketplace has been subject to the many crosswinds of change since World War II. The overriding movement that has occurred since the end of the 1970s has been in the direction of less dependence on government and more reliance on the private sector."1 British Prime Minister Margaret Thatcher and President Ronald Reagan led this revolution to privatization. Nowadays, every country is undergoing such a process.

Because too many subjects under the same microscope may obscure the picture with this word, this article explores from a comparative perspective a precise form of privatization and its consequences on public law values.

Privatization is broadly defined as "the shifting of a function, either in whole

* Ph.D. candidate, University of Panthéon-Assas (Paris II), and Adjunct Professor, University of Paris X-Nanterre, mtirard@u-paris10.fr. I would like to thank Professor Alfred C. Aman, Jr. for inviting me to the Indiana Journal of Global Legal Studies Symposium on Democracy and the Transnational Private Sector, Indiana University School of Law-Bloomington and to Indiana University for such a great experience. I would also like to deeply thank Professor Elisabeth Zoller for her precious comments. Special thanks to Pauline Abadie.

1. Paul Seidenstat, Contracting Out Government Services 3 (1999). 
or in part, from the public sector to the private sector." Because the concept does not refer to the same realities in the United States and in Europe, ${ }^{3}$ this article makes the choice of a pragmatic approach.

Privatization has known a variety of forms all around the world for a few decades, and the list of specific techniques frequently associated with it can be a lengthy one. The most common instruments are contracting out and selling government-owned assets, but broader definitions exist and include a wide range of public-private partnerships, ${ }^{4}$ such as vouchers. ${ }^{5}$ However, vouchers are less common in Europe. ${ }^{6}$ That is why, at first glance, this article only focuses on the transfer of state assets and state functions to private hands.

Differences still exist between the European and the American debates within such a scope of analysis. Matthew Crenson states that "[i]n the United States, privatization rarely means the outright sale of public assets to private purchasers. ... In most cases ... privatization refers to the use of nongovernmental organizations to run government programs." Thus, the pattern of privatization typically followed in the United States means "retaining collective financing but delegating performance to the private sector." ${ }^{8}$ Therefore, contracting out is fundamental. ${ }^{9}$

2. Harvey B. Feigenbaum et al., Shrinking the State: The Political Underpinnings of Privatization 1 (1999); see also Black's Law Dictionary 1214-15 (7th ed. 1999) ("[ $t$ ]he act or process of converting a business or industry from governmental ownership or control to private enterprise").

3. Whereas in the United States "privatization" is generally used as a generic term, there is a distinction in Europe between "privatization," "deregulation," and "liberalization." For a discussion of the differences between privatization in the United States and in Europe, see Giandomenico Majone, Paradoxes of Privatization and Deregulation, 4 Eur. Pub. Pol’y 53 (1994).

4. See generally Christopher Hood, Tools of Government (1986); Lester M. Salamon, The Tools of Government: A Guide to the New Governance (2002).

5. See, e.g., C. Eugene Steuerle et al., Vouchers and the Provision of Public Services (2000).

6. See Arthur B. Ringeling, European Experience with Tools of Government, in SA LAMON, supra note 4, at 585-99.

7. Matrhew A. Crenson \& Benjamin Ginsberg, Downsizing Democracy: How America Sidelined Its Citizens and Privatized Its Public 202-03 (2002).

8. John D. Donahue, The Privatization Decision: Public Ends, Private Means 7 (1989); see also Seidenstat, supra note 1, at 9 ("[T] he dominance of contracting out [in the United States] as the preferred method of privatization [at the state level at least] is clear. Overall, in 1993, 78 percent of state agencies used contracting out as the primary privatization device. The pattern at the local level also reflects this pattern."); Jody Freeman, Private Parties, Public Functions and the New Administrative Law, 52 Admin. L. Rev. 813, 821-22 ("In the United States, many social services have long been funded by government agencies but provided by non-government actors. Other services, such as prison operation, have been traditionally performed by government and only recently contracted out to market.").

9. Steven J. Kelman, Contracting, in Salamon, supra note 4, at 283 (making a distinction between "contracting for procurement of products and services used directly by the government 
By contrast, in Europe and especially in France, ${ }^{10}$ the debates have historically focused on the sale of state enterprises. ${ }^{11}$ Although very common, the topic of contracting out has not received much attention in comparative analysis. The French perspectives and findings, however, may be interesting for the United States, especially those regarding la délégation de service public. ${ }^{12}$ That is why this article mainly explores contracting out, ${ }^{13}$ even if privatization can be defined in a larger sense.

A study on privatization raises a certain number of issues, and notably questions the fate of public law values. ${ }^{14}$ Because the French and American conceptions of public law are different, ${ }^{15}$ the French experience can provide thoughtful insights to the American debates over the protection of these values in the process of contracting out public functions.

In general terms, the French debate over privatization must be analyzed in the light of a profound cultural preoccupation with the state and its purposes-a preoccupation that is alien to British and American political cultures. As opposed

agency and contracting for the delivery of government-funded services by third parties to external recipients."). The distinction is close to the French one between marchés publics and délégations de la gestion de services publics (or délégations de services publics). This article focuses on the second category. The contractual device is useful to describe such a transfer of state functions to the private sector but also contractual approaches to regulation. See, e.g., Jody Freeman, The Contracting State, 28 Fla. ST. U. L. Rev. 155, 155 (2000) (assuming that "[t]he modern administrative state might aptly be dubbed 'the contracting state"'). However, this article does not explore regulation.

10. See, e.g., Cosmo Graham \& Tony Prosser, Privatizing Public Enterprises: Constitutions, the State, and Regulation in Comparative Perspectives 105-137 (1991); Nikolaos Zahariadis, Markets, States, and Public Policy: Privatization in Britain and France 3-16 (1995).

11. For a recent analysis, see Michel Berne \& Gérard Pogorel, Privatization Experiences in France, in Marko Kothenburger et al., Privatization Experiences in the European Union 163-97 (2006).

12. See generally Kelman, supra note 9. The délégation de service public in France is open for both public and private contractors, even if private parties are most of the time involved. Public authorities may delegate either a "public service industrial and commercial" (service public industriel et commercial) or a "service public administrative" (service public administratif). Their legal regimes are different. See infra Part II for details.

13. However, privatization of the assets in France must be studied in order to understand contracting out. That is why this article deals with it. See infra Part I.A. for details.

14. For a global analysis, see Ellen Dannin, Red Tape or Accountability: Privatization, Publicization, and Public Values, 15 Corn. J. L. \& Puв. Pol'y 111 (2005); Mark H. Moore, Introduction to Symposium: Public Values in an Era of Privatization, Introduction, 116 Harv L. Rev. 1212 (2003).

15. In the common law world, "public law" refers to " $[\mathrm{t}]$ he body of law dealing with the relations between private individuals and the government, and with the structure and operation of the government itself; constitutional law, criminal law, and administrative law taken together." BLACK's Law Dictionary, supra note 2, at 1244. This article focuses on constitutional and administrative laws. There is the same formal definition in France; however, "public law" is more directly connected to the Roman conception of the res publica. Elisabeth Zoller, Introduction To Public Law: A Comparative Study 3 (2008). 
to the common law tradition that equates government and state, civil law countries make a clear distinction between the two concepts. In French public law, the state is not the government but rather the res publica. ${ }^{16}$

In the common law tradition, the basic model of constitutionalism denotes negative limits on state action. Reflecting this classical distrust of the state, the Constitution of the United States imposes various restrictions on the exercise of governmental power. ${ }^{17}$ Administrative law has also followed these outlines. Therefore, the U.S. government has very few substantive rights. Public law and its values such as accountability, due process, and fairness, are mainly procedural. Furthermore, because state actors trigger constitutional and administrative protections while non-state actors usually do not, ${ }^{18}$ the use of private parties to perform public functions ${ }^{19}$ obstructs the protection of these values. ${ }^{20}$

In France, by contrast, the state has always been considered indispensable because of its role in protecting and developing the res publica. ${ }^{21}$ Consequently, it has positive rights and duties. This particularism must be understood within the French Republican model and its conception of "public interest" (l'intérêt général) and "public service" (le service public). It explains why public law values from a French perspective are more substantive than procedural and refer to the motto of the Republic: "liberty, equality, fraternity" (liberté, égalité, fraternité). Hence, public law norms may apply to private parties. Therefore, public law values do not disappear with privatization.

This background helps explain what can be considered a paradox. The new policy regarding privatization in France was triggered by the same factors as else-

16. ZoLLER, supra note 15 , at 199.

17. U.S. ConsT. amend. I ("Congress shall make no law"); U.S. Const. amend. XIV, § 1("nor shall any state deprive any person of life, liberty, or property without due process").

18. Regarding the problems of the state action doctrine, see, for example, Daphne Barak-Erez, A State Action Doctrine for an Age of Privatization, 45 Sy racuse L. Rev. 1169, 1183-86 (1995); Erwin Chemerinsky, Rethinking State Action, 80 NW. U. L. Rev. 503, 534-35 (1985); Robert S. Gilmour \& Laura S. Jensen, Reinventing Government Accountability: Public Functions, Privatization, and the Meaning of "State Action," 58 Pub. Admin. Rev. 247 (1998).

19. This trend is referred to as "government by proxy" or "third-party government." Donald F. Kettl, Government by Proxy: (Mis?) Managing Federal Programs (1987); Lester M. Salamon, Rethinking Public Management: Third-Party Government and the Changing Forms of Government Action, 29 Pub. Pol'y 255 (1981).

20. It is generally considered as a source of a democracy deficit. See, e.g., Alfred C. Aman, Jr., The Democracy Deficit: Taming Globalization Through Law Reform (2004).

21. Something close is the Charles River Bridge case in which Chief Justice Taney declared that "the object and end of all government is to promote the happiness and prosperity of the community by which it is established." Charles River Bridge v. Warren Bridge, 36 U.S. 420, 422 (1837). 
where and resulted in a great shift from the public to the private sector. However, the conditions and consequences of privatization have been different in France than in the United States. In particular, the French government has shrunk, but the reach of public law has not receded. The reasons are twofold: first, the French government maintains core governmental functions within the public sphere (Part I); second, public law norms still cover privatized functions (Part II).

\section{The Scope of Privatization}

Like many other states, France has undertaken programs to privatize both public enterprises and public functions. As for the United States, scholars wonder if privatization is (or may be) limited by current U.S. law, ${ }^{22}$ but in practice nearly all activities seem open to privatization. ${ }^{23}$

The French particularism helps explain by contrast why such processes meet limitations, expressed through concrete illustrations. ${ }^{24}$

22. See, e.g., Clayton P. Gillette \& Paul B. Stephan III, Constitutional Limitations on Privatization, 46 Ам. J. Сомp. L. 481, 482 (1998) ("It is hard to identify any function that, as a constitutional matter, has been characterized as inherently public. In particular, we cannot find any decision that unambiguously declares than [sic] any particular governmental service may not be contracted out to private providers."); Ronald C. Moe, Exploring the Limits of Privatization, 47 Pub. Admin. Rev. 453 (1987); Jody Freeman, Private Role in Public Governance, 75 N.Y.U. L. Rev. 543, 581 (2000) ("The federal government thus retains considerable flexibility to make substantial delegations of its responsibilities, and even of functions closely associated with core sovereign powers, to private parties."). Therefore scholars often try to limit the privatization situations. See, e.g., Gillian E. Metzger, Privatization as Delegation, 103 Colum. L. Rev. 1367 (2003); Paul R. Verkuil, Public Law Limitations on Privatization of Government Functions, 84 N.C. L. Rev. 397, 401 (2006) [hereinafter Public Law Limitations]; Paul R. Verkuil, The Non Delagable Duty to Govern (Cardozo Legal Studies Research Paper No. 149), available at http://papers.ssrn.com/sol3/papers.cfm?abstract _id $=871455$.

23. The argument in the United States on exclusively public functions exists but is really different from the French one. See, e.g., Flagg Bros. Inc. v. Brooks, 436 U.S. 149, 164 (1978) (including "education, fire and police protection, and tax collection" as public functions, but explicitly withholding judgment as to whether government "might be free to delegate to private parties the performance of such functions and thereby avoid the strictures of the Fourteenth Amendment").

24. Thus, the French experience could enrich American debates. See, e.g., Verkuil, Public Law Limitations, supra note 22, at 401 ("Accepting privatization ... need not mean the end of public law; indeed, public law limitations must be satisfied before some government functions can be outsourced"). 


\section{A. Privatization in the French Context}

Because of the particular nature of the debate in France over the state and the market, the very definition of privatization has undergone certain theoretical limitations.

\section{The Background: the Debate over the State and the Market}

The role of state intervention in the French economy has been sizable since the time of Louis XIV. Some of the tasks of the "Nation" were already mentioned in the 1789 Declaration of the Rights of Man and of the Citizen. ${ }^{25}$ Here lie the roots of the French particularism regarding privatization.

The present French Republican model is based on the concept of public service, which is "la raison d'être de l'Administration." define for Anglo-Saxon lawyers. ${ }^{27}$ The most comprehensive definition comes from Bernard Schwartz, who noted in a broad sense that a public service is "a means provided by the public authorities to satisfy general social needs." ${ }^{28}$ It has been considered the foundation of French administrative law, ${ }^{29}$ and some authors even tried to build a conception of the state on the notion. ${ }^{30}$

Since the end of the nineteenth century, public services have been considered indispensable tools to the functioning and development of society. Orchestrated around the state and around the French conception of the res publica, France has long been considered a "cooperation of public services." ${ }^{\text {" }}$ A turning point in that history is the Preamble to the 1946 Constitution, which contains many provisions

25. See, e.g., article 12: "To guarantee the Rights of Man and of the Citizens, a public force is necessary." Article 13: "For the maintenance of the public force, and for administrative expenses, a general tax is indispensable." Translations are from VICKI C. Jackson \& MARK Tushnet, Comparative Constitutional Law 565 (1999).

26. René Chapus, Droit Administratif General Volume 1, at 573 (15th ed., 2001).

27. It is harder to define it in English. Tony Prosser summarizes it as "an activity in the general interest, provided by a public or private actor and subject to a special legal regime requiring equality of treatment, adaptation to changing needs and security of supply, etc." Tony Prosser, Public Service Law: Privatization's Unexpected Offspring, 63 Law \& Contemp. Probs. 63, 76 (2000). But he added in a footnote that his " $[\mathrm{t}]$ ranslation is a loose one in view of the difficulty in conveying the flavour of the concept in English." Id.

28. Bernard Schwartz, French Administrative Law and the Common-Law World 68 (1954) (quoting Appleton, Traite Elementaire de Contentieux Administratif 114 (1927)).

29. See id. at 1-18 (providing a good introduction to general principles of French administrative law).

30. Léon Duguit, The Concept of Public Service, 32 Y ALE L. J. 425 (1923).

31. Id. at 431 . 
regarding state duties, including education, ${ }^{32}$ health care, and general welfare. ${ }^{33}$ The most important provision concerning privatization states, "all property and all enterprises that have or that may acquire the character of a (national) public service or a de facto monopoly shall become the property of society. ${ }^{34}$

The importance of public services has been implemented in two ways: through public direction ${ }^{35}$ and granting public service delegations for private concerns. Thus, private enterprises have always contracted with the Administration to fulfill public activities. ${ }^{36}$ Public service is not, and has never been, synonymous with public ownership.

Since the end of the 1970s, the dominant global trend has been towards the direction of less dependence on government and more reliance on market mechanisms. ${ }^{37}$ Underlying much of this reform surge is a set of theorics that portrays government agencies ${ }^{38}$ as tightly structured hierarchies insulated from market forces and citizen pressure, and therefore free to serve the personal and institutional interests of bureaucrats instead..$^{39}$ Private initiative has been favored over state intervention, and France has not been an exception to this general trend.

However, the French debates over privatization were particularly active during the 1980 s because of the specificities regarding public services. Some French scholars even argued that certain public services could not be privatized due to their govern-

32. 1946 Const. pmbl. $\$ 13$ ("The Nation guarantees equal access for children and adults to instruction, vocational training and culture. The provision of free, public and secular education at all levels is a duty of the State.").

33. Id. at $\$ 11$ ("[The Nation] shall guarantee to all, notably to children, mothers and elderly workers, protection of their health, material security, rest and leisure. All people who, by virtue of their age, physical or mental condition, or economic situation, are incapable of working, shall have to the right to receive suitable means of existence from society.").

34. Id. at $\$ 9$.

35. Public direction has been organized through either public enterprises (especially after World War II with nationalizations of electricity and gas) or other legal forms (the most common is the régie).

36. See, e.g., Conseil d'Etat [CE] [highest administrative court], Jan. 10, 1902, Gaz de Devillelčs-Rouen Rec. Lebon 5. But private companies have also been involved in carrying out public services without any contract with public authorities. See, e.g., CE Ass., May 13, 1938, Caisse Primaire Aide et Protection Rec. Lebon 417.

37. See, e.g., David E. Osborne \& Ted A. Gaebler, Reinventing Government: How the Entrepreneurial Spirit is Transforming the Public Sector (1992) (one of the most important books in this global trend); Susan Strange, The Retreat of the State: The Diffusion of Power in the World Economy (1996); World Bank, World Development Report i997: The State in a Changing World (1997).

38. The word "agency" refers to the American experience. Concerning France, this article refers to "Administration" or "public entity/authority."

39. See, e.g., James M. Buchanan \& Gordon Tullock, The Calculus of Consent (1962). 
mental nature..$^{40}$ In practical terms France was the exception, at least initially, to the worldwide privatization trend. It experimented with Keynesianism in 1981, just as its partners were abandoning the approach, and extended, rather than retracted, the state by nationalizations. Nevertheless, in 1986, the coalition of right parties came to power and passed laws authorizing the denationalization of public firms. ${ }^{41}$

Consequently, the Constitutional Council, the highest judicial body in constitutional matters, was asked to answer the fundamental question of whether there are limitations to privatization.

\section{Theoretical Limits: Core Governmental Functions}

The Constitutional Council declared in 1986 that some core governmental activities and corresponding public services cannot be privatized because they derive from the Constitution. ${ }^{42}$ These public services, called "constitutional public services, ${ }^{133}$ include justice, police, defense, education, and health care. ${ }^{44}$ The Council reached the same findings in several matters regarding the sale of public enterprises. ${ }^{45}$ Today, every public firm seems open to privatization because none of them express constitutional functions. ${ }^{46}$

This concept resonates with Anglo-Saxon experiences ${ }^{47}$ It is, for example, at odds with Tony Prosser's findings, which noted a few years ago that "the United Kingdom experience shows quite clearly that there is no core governmental activity which cannot be privatized.948

40. See infra Part I.A.2.

41. Law No. 86-793 of July 2, 1986, Journal Officiel de la République Française [J.O.] [Official Gazette of France], July 3, 1986, p. 8240.

42. Conseil constitutionnel [hereinafter CC] decision no. 86-207 DC, June 25-26, 1986, J.O., June 27,1986 , p. 7978 at $\$ 53$, available at http://www.conseil-constitutionnel.fr/decision/1986/ $86207 \mathrm{dc} . \mathrm{htm}$.

43. See, e.g., Louis Favoreu, Service public et Constitution, AJDA 16 (June 20, 1997).

44. See infra Part I.B. for details.

45. See, e.g., CC decision no. 87-232 DC, Jan. 7, 1988, J.O. 482; CC decision no. 96-380 DC, July 23, 1996, J.O. 11408; CC decision no. 2006-543 DC, Nov. 30, 2006, J.O. 18544.

46. See, e.g., Jean-Pierre Duprat, les Garanties Constitutionnelles à l'Epreuve des Privatisations, rapport français pour le Congrès de l'AIDC (2007), available at www.afdc.fr.

47. The French findings are close to some American debates. See, e.g., Kelman, supra note 9, at 307 ("certain activities are regarded as 'inherently governmental' because they involve making policy decisions or rely on the government's monopoly of the legitimate use of violence, and therefore are inappropriate for contracting no matter what the other advantages of contracting might be. This argument would apply to contracting out diplomacy or IRS tax enforcement, and could, in my view, convincingly be applied to contracting out the operation of prisons or welfare benefit determination decisions."). See generally supra note 22.

48. Tony Prosser, Social Limits to Privatization, 21 Brook. J. INT'L. L. 213, 218 (1995). 
If the Constitutional Council has mostly dealt with cases concerning privatization of public firms, ${ }^{49}$ the French movement toward contracting out has nevertheless been also essential. Private companies are now involved in performing many public services, such as the provision of water and transportation, as well as more traditional public activities such as education. The potential scope of this movement must be understood with the same reasoning: because some functions are considered the core of public life-the core of the government, they cannot be privatized, regardless of the form (transfer of public assets or public functions) or the beneficiary of privatization (profit or nonprofit organizations). The practical implementation of such a rule concerning contracting out has been carried out by the Council of State. ${ }^{50}$

It is important to detail the prohibition before making it explicit with concrete examples. Indeed, some activities within a constitutional public service may be open to delegation. There is a distinction within such a public service between the core governmental function per se on the one hand, that is to say the genuine fundamental public activity protected by the Constitution, and a complementary function on the other. For example, delegating the provision of food service in a police station seems less problematic than delegating the control of people in the streets. As the general principle stated above, the former activity can be outsourced, the latter cannot.

There is a second and more disturbing situation in which core governmental functions are entirely open to delegation. The most important sectors are education and health care. That is why scholars draw a distinction within constitutional public services between those linked to sovereignty (e.g., police and defense), and the rest (e.g., education and health care). ${ }^{51}$

Given the complexity of the theory, the article turns now to more concrete examples.

\section{B. Concrete Limitations to Privatization}

Although non-exhaustive, the following discussion will brush through various examples that are relevant to the French experience. ${ }^{52}$

49. The only case directly dealing with contracting out is CC decision no. 90-285 DC, Dec. 28, 1990, J.O., p. 16609. See infra note 69 for details.

50. See infra Part I.B. for concrete examples.

51. See Favoreu, supra note 43.

52. Because of the complexity, this article will only take a general stand. For details, see CE, Oct. 7, 1986 in Yves Gaudemet et al., Les grands avis du conseil d'Etat 333-34 (2d ed. 2002). 


\section{Policing Activities}

The Council of State has always ruled that core governmental functions such as controlling and punishing citizens cannot be contracted out. ${ }^{53}$ However, complementary activities such as the organization of street parking, vehicle towing, or teleprocessing may be delegated because they are not directly connected with this core. ${ }^{54}$

For the past twenty years, France has enacted legislations allowing private actor involvement in policing activities, especially in airports and malls..$^{55}$ Nevertheless, they are neither allowed to control nor to arrest people and are strictly supervised by public authorities. Private participation in this field seems more restricted and at the same time more controlled than in the United States. ${ }^{56}$

\section{Prisons and Justice}

Similar to prohibitions against policing activities, French law restricts delegation of justice and prison activities; specifically, the control and punishment of citizens, deprivation of liberty, and custodial functions.

With respect to prisons, privatization covers a wide spectrum of issues. It starts in areas that are not generally contentious, such as issuing commercial contracts for the canteen or shop in which prisoners can purchase items for their personal use. The next stage in privatization is that in which specific services, such as drug treatment or other programs for prisoners, are delivered by commercial companies or nonprofit organizations. Moving further along the spectrum, in some cases contracts are issued for the central services within the prison. The contracts can include custodial activities, supervision, and education of prisoners.

Privatization of prisons was an important issue in France in 1987 when the government decided to expand accommodation and invited the private sector to participate. At the outset, the expectation was that the operation of these new prisons should be wholly privatized, that is to say all functions would have been contracted out to the private sector, from garbage removal to education and man-

53. CE, June 17, 1932, Ville de Castelnaudary Rec. Lebon 595; CE, Apr. 1, 1994, Commune de Menton Rec. Lebon 176; CE, Dec. 29, 1997, Commune d'Ostricourt Rec. Lebon p. 706.

54. CE, Mar. 20, 1998, SEM de Sécurité active et de télématique, Rec. 1022.

55. Law No. 2003-1119 of Nov. 26, 2003, J.O., Nov. 27, 2003, p. 201396; Law No. 2003-239 of Mar. 18, 2003, J.O., June 5, 2003, p. 9561; Law No. 96-73 of Jan. 21, 1995, J.O., Jan. 24, 1995, p. 1249 ; Law No. 96-151 of Feb. 26, 1996, J.O., Feb. 27, 1996, p. 3094; Law No. 89-467 of July 10, 1989, J.O., July 11, 1989, p. 8672; Law No. 83-629 of July 12, 1983, J.O., July 13, 1983, p. 2155.

56. Cf. Elizabeth E. Joh, Conceptualizing the Private Police, 2005 Uтан L. Rev. 573, 609-11 (2005) (for a comparison with the United States); David Alan Sklansky, Private Police and Democracy, 43 AM. Crim. L. Rev. 83 (2006) (for a debate over democracy). 
agement. But in the face of opposition from various sources, privatization of the core operational side was cancelled before it even got under way. Management and custodial functions therefore remained as public functions. However, the hotel functions and prison industries were awarded to private companies. ${ }^{57}$

This system of dual management, often described as semiprivate prisons (prisons semi-privées), has increased in France since $1987 . .^{58}$ Even if France privatized some functions in prisons, the state has firmly retained control of the actual deprivation of liberty. In France, unlike the United States, punishment is a state responsibility and entitlement. Privatization of such core functions would be the abandonment of a governmental task..$^{99}$

\section{Defense}

The French Department of Defense declared a few years ago that present delegations include activities such as guarding, food service provision, and accommodation. Its next agenda is clear because contracting out will be pursued when private parties are able to bring specific skills and qualifications in sectors that are not linked to the hearth of the activity of defense. ${ }^{60}$

It follows that France seems less concerned with problems faced by the United States in the activities of war. ${ }^{61}$ The operation in Iraq since 2003 has been a turning point, even if the involvement of private companies has been rising for a few decades. In Iraq, private companies participate in the whole activity of war because they have been providing logistics and site security. In addition, they have supplied supporting weapons systems, advice and training, and armed personnel that operate with troops on the battlefield..$^{62}$

57. Law No. 87-432 of June 22, 1987, J.O., June 23, 1987, p. 6775.

58. Law No 2002-1094 of Aug. 29, 2002, J.O. Aug. 30, 2002, p. 14398. France has very recently embarked on a prison building program of new semi-private prisons. See http://www.justice.gouv.fr/ index.php? rubrique $=10036 \&$ ssrubrique $=10262 \&$ article $=14148$

59. However, private firms have been allowed since 2002 to carry out electronic supervision of prisoners because such activities are not connected to State sovereignty (CC decision no. 2002-461 DC, Aug. 29, 2002). See infra note 69 for details.

60. Law No. 2003-2008, Jan. 27, 2003, J.O., Jan. 29, 2003, p. 1744.

61. See, e.g., Jon D. Michaels, Beyond Accountability: The Constitutional, Democratic, and Strategic Problems with Privatizing War, 82 WASH. U. L.Q. 1001 (2004) (explaining difficulties facing countries seeking to privatize even functions that are not inherently governmental); Martha Minow, Outsourcing Power: How Privatizing Military Efforts Challenges Accountability, Professionalism, and Democracy, 46 B.C. L. Rev. 989 (2005) (indicating further problems facing the United States with privatization in the military complex).

62. Deborah Avant, The Privatization of Security and Change in the Control of Force, 5 InT'L Stud. Persp. 153, 153 (2004). 


\section{Education ${ }^{63}$}

Education is mentioned in the French Constitution as a state duty. ${ }^{64}$ Therefore, as a constitutional public service, education should theoretically not be open to delegation. ${ }^{65}$ The Constitutional Council, nevertheless, stated in 1977 that people have a freedom of choice between public and private education. ${ }^{66}$ Consequently, there are both public and private schools in France. ${ }^{67}$ As in other constitutional public services, the only activities that may be delegated in the former are the complementary functions (e.g., provision of food service and transportation). By contrast, in the latter, the fundamental functions of education can also be provided by the private sector, even if a few limitations exist. ${ }^{68}$

Education reveals surprising findings due to the broad participation of private actors in a core governmental function. Moreover, it is not always easy to determine within such an activity whether a particular mission is open to delegation or not. ${ }^{69}$ Nevertheless, it does not mean that the category of constitutional public services is an "empty bag." ${ }^{.70}$ Indeed, the limited scope of privatization only represents the first aspect of the French protection of public values, which must be evaluated hand in hand with its legal regime.

63. The following discussion equally applies to health care.

64. 1946 Const., supra note 32.

65. The debates were important at the beginning of the $1980 \mathrm{~s}$, and particularly in 1984 , when the government failed to subordinate all private schools to the same regime as public schools.

66. CC decision no. 77-87 DC, Nov. 23, 1977, J.O. 5529.

67. Today around $20 \%$ of young people in France attend private schools. See http://www .education.gouv.fr/cid195/les-chiffres-cles.html.

68. Cass. Crim 3 avril 2002, Soc. SGTE Travaux électriques, cne de Saint-Maur-des-Fossés et Cie Axa Assurances, BJCE, septembre 2002, $\mathrm{n}^{\circ}$ 24, p. 367, concl. D. Commaret, (applying to all schools).

69. For example, the supervision of prisoners is quite disturbing. This activity cannot be theoretically delegated, but the electronic supervision is delegable because it has been considered as distinct from core governmental functions. See supra note 59. Another example is tax matters. See CC decision no. 90-285 DC, supra note 49 (the Council stated that tax collection, which is at the heart of the governmental functions, may be delegated to a private actor when the public authority remains in charge or exercises a control). In comparison, in the United States, the IRS has recently used private companies to collect federal income taxes (beginning with the 2004 American Jobs creation Act).

70. See, e.g., Ramu de Bellescize, Les Services Publics Constitutionnels 244 (2005). 


\section{The Legal Regime of Privatization}

Public law norms are theoretically inapplicable when a function has been privatized in the United States. ${ }^{71}$ Therefore, the private contractor seems almost free to deliver the service as it deems appropriate. ${ }^{72}$

In France, by contrast, as soon as the service is connected with the public interest, private parties are subject to specific public law precepts. Consequently, contracting out does not mean the eviction of public law values. ${ }^{73}$ This solution is deeply rooted in the French legal history. Indeed, if one objective of public law is to protect the interests and rights of individuals against invasion by the government, as is the case in the United States, it also has to be reconciled with a sense of the community. ${ }^{74}$

Two sets of rules apply to the French regime of contracting out. ${ }^{75}$ First, by their very nature, public activities and related public services trigger the application of some general public law obligations-it is the public service " $a$ la française." Second, other specific requirements apply directly to the delegations.

71. See supra Introduction.

72. But see Jack M. Beermann, Administrative-Law-Like Obligations on Private(ized) Entities, 49 UCLA L. Rev. 1717 (2002) (arguing that privatization and deregulation usually come with strings attached under which private entities are required to comply with governmentally prescribed standards of various forms and degrees of stringency). It depends in practice on the terms and conditions of the contract.

73. For a comparison with the United States, see the agenda set forth by Alfred C. Aman, Jr., The Limits of Globalization and the Future of Administrative Law: From Government to Governance, 8 IND. J. Global Legal Stud. 379, 384-85 (2001) (advocating "the extension of various procedural approaches developed for the public sector to the private sector, albeit in new forms, so as to provide greater transparency and accountability by private actors who carry out the public's business... The new administrative law should be one that focuses more on the functions and effects of the power exercised over citizens and less on the definitional criteria by which one might distinguish the public and private nature of the entities that actually exercise that power."). See also Jody Freeman, Extending Public Law Norms Through Privatization, 116 Harv. L. Rev. 1285 (2003) (writing on the potential for the state to "extend its reach" into the private sector through incorporation of public interest values into private contracts and arguing that instruments such as budgeting, regulation, and contracts may extend the province of public law); Paul Verkuil, Privatizing Due Process, 57 Admin, L. Rev. 963 (2005); sources cited supra note 18 (concerning the reforms of the state action doctrine).

74. See CE, Réflexions sur l'intétêt général, in Rapport Public 239-357 (1999).

75. See, e.g., L. Neville Brown \& John S. Bell, French Administrative Law (5th ed. 1998); Chapus, supra note 26; Pierre Devolve, Le Droit Administratif (4th ed. 2006); Schwartz, supra note 28; Jurgen Schwarze, European Administrative Law 100-13 (2006) (for a European perspective); Jean-Bernard Auby, Administrative Law in France, in Rene seerden \& Frits Stroink, Administrative Law of the European Union, Its Member States and the United States 59-89 (2002). 


\section{A. The General Rules: Public Service "à la Française"}

Two situations reflect the importance of public law values in France and the spirit of their protection. The first one is directly connected with the concept of public service. The second situation applies more specifically to constitutional public services within which whole delegations are awarded.

\section{Basic Public Law Requirements: les Lois du Service Public}

The concept of public service, broadly defined as a means provided by the public authorities to satisfy general social needs, ${ }^{76}$ is as essential to comprehending the regime of contracting out as it is to understanding its scope.

Public service triggers the application of some legal obligations, known as the "public service principles" (les lois du service public). Whether a public service is operated by a public authority itself or by a private enterprise under administrative authorization, these basic public law precepts apply. ${ }^{77}$ Thus, the province of public law extends to private actors in such situations. ${ }^{78}$ Tony Prosser was right when he stated that "[s]ervice public may also be a means of incorporating certain social principles into the operation of private enterprises in the market place."79

The three principles governing all public services include:

\section{a. Adaptability}

The provision of a public service must adapt to evolving circumstances as may be required by the public interest. For instance, even when the activity has been delegated to a private actor, the Administration is nevertheless allowed to unilaterally modify the contractual obligations if need be, regardless of the precise wording of the contract. ${ }^{80}$

\section{b. Continuity}

The provision of a public service cannot be interrupted except in precise circumstances provided by the law. ${ }^{81}$ The consequences are twofold. On the one

76. See supra Part I.A.1. For purposes of this part, "public authority," "Administration," and "State" are synonymous terms that refer to "government" or "agencies" in the United States.

77. But the converse is also true. If a specific activity does not come within the concept of public service, then cases concerning it are within the competence of the French civil courts, even if the particular activity happens to be one carried on by a public authority.

78. They are the minimum norms applicable to all public services. See CC decision no. 2004-501 DC, Aug. 5, 2004, Rec. 134.

79. Prosser, supra note 27, at 76.

80. See infra Part II.B. for more concrete details.

81. See CC decision no. 79-105 DC, July 25, 1979, Rec. 33 (holding that this principle is protected by the Constitution); CE, June 13, 1980, Mme Bonjean Rec. Lebon 274. 
hand, public agents have to respect some specific rules regarding strikes. On the other, it justifies the powers of public authorities in the implementation of the delegation, especially the power to sanction the private actor. ${ }^{82}$

\section{c. Equality}

The Constitution globally protects the principle of equality before the law and, by so doing, equality before the public services. It also implies the neutrality of the public service..$^{83}$ The courts insist that all citizens should have an equal opportunity of benefiting from public services. Unfair discrimination is strictly forbidden.

\section{Extension of Public Law Norms to Delegated Constitutional Public Services}

Education and health care, although considered constitutional public services, are sometimes wholly delegated to private hands. ${ }^{84}$ Nevertheless, the state and public law requirements remain very active. ${ }^{85}$

\section{a. Education $^{86}$}

A statute enacted in 1959 regulates the relations between the state and private schools. These schools theoretically have the choice to either contract with the state or not. In reality, nearly all of them enter into a contract with the government for financial assistance in exchange for their adherence to certain rules and controls. ${ }^{87}$

Under the terms of the "simple contract" (contrat simple) which applies to elementary schools, the government pays the salaries of teachers provided they hold the requisite teaching qualifications. These private schools must also respect the basic rules of public education. Secondary schools, which are the common private schools,

82. See infra Part II.B. for details.

83. Neutrality is often considered as the fourth principle. See, e.g., CC decision no. 86-217 DC, Sept. 18, 1986, Rec. 141; CE, May 3, 2000, Mlle Marteaux J.O., June 23, 2000, p. 9471 . The consequences of neutrality are important, especially for religious matters. Debates are particularly important at school.

84. See supra Part I.

85. This regime is important due to the specific legal nature of outsourcing involved in such circumstances. Because they are not always considered from a legal point of view as délégations de services publics, the public services principles may not be applicable as such (especially in education). It follows that public law norms through control and regulation are considered as fundamental to guarantee public law values. Similarly, the following rules, infra Part II.B., are also applicable to these situations. See Jacques Chevallier, Lassociation au service public, JCP-G 2267 (1974); Nicole Fontaine, LA LIberte D'enseignement, De La Loi Debre A La Loi Guermeur 102-03 (1978) (for education).

86. See, e.g., Howard D. Lewis, The French Education System (1985) (providing a history of French education).

87. If today around $20 \%$ of young people in France attend private schools, $97.4 \%$ of them study in a school which has entered into a contract with public authorities. See supra note 67. 
enter into a "contract of association" (contrat d'association) under which the state pays the salaries of teachers who are public employees and provides operating expenses. Such private schools agree to follow the same curriculum as the public sector.

In addition, the state supervises all private schools. The degree of supervision becomes even greater when the school enters into a contract with the government (financial control).

So in such cases, contracting out is far from being a complete privatization without public law requirements.

\section{b. Health Care}

The role of the state is also fundamental for private health care. One must draw a distinction between two connected steps: financing and regulation. As James Russell states, "[t]he majority of health care spending in Europe is publicly financed. In the United States the majority is privately financed." ${ }^{88}$ Consequently, "the major actors in the American health system ... are immune to government regulation or control as they are in Europe." ${ }^{\prime 9}$

In practical terms, almost all private actors involved in health care in France must comply with regulations enacted by a public authority. They are also more or less supervised in the implementation of their tasks.

Once again, contracting out does not result in the release from public law duties.

\section{B. The Specific Rules Governing the Relations of the Private Contractor}

In addition to the general rules previously analyzed, there are several specific rules that address the relations of the private contractor to the Government and to private parties.

\section{Relations with the Government}

The rules applicable to both the government and the private contractor are determined by the nature of the contract.

\section{a. The Basis: the Legal Qualification of the Contract}

As elsewhere, French public authorities generally enter into contracts for outsourcing public services. In France, such contracts are administrative because of

88. James W. Russell, Double Standard: Social Policy in Europe and the United States 123 (2006).

89. Id. at 123-24. 
the very nature of the public services granted. This qualification is fundamental due to the specific rules that will apply: the public entity is the leader of the contract and has specific powers. Georges Langrod was right when he stated in the middle of the twentieth century that with the notion and the regime of administrative contracts, France ensures

the regularity and continuity of public services through a special legal and technical conception which seems more effective and at the same time more elastic than analogous devices known to private law. ... This justifies also the submission of administrative contracts to a specific legal status, founded on clauses exorbitantes unknown in private law..$^{90}$

This legal status justifies the general power for public authorities to oversee the execution of a contract and to control its termination, notwithstanding its precise terms. That is to say, many powers are deemed d'ordre public: they may be applied even if there is no formula (or another formula) in the contract. Then the French conception of the public interest can permit what would be considered in the United States as a breach of contract by public entities. In such cases, the law of the contract is not always the law of the parties.

\section{b. Specific Powers of Public Authorities ${ }^{91}$}

- The provision of public services is strictly supervised by public authorities. This control can be extended to all needed measures, except that the Administration cannot be regarded as exercising the mission itself;

- If the private party fails to carry out its mission, the Administration can levy specific penalties without prior recourse to a court. These penalties may be financial or coercive;

- Public entities can also unilaterally modify the contract. The public entities have powers to redefine the character of the service to be performed or the work to be done in order to meet the changing needs of the public interest (the financial ele-

90. Georges Langrod, Administrative Contracts. A Comparative Study, 4 Aм. J. Coмp. L. 325 , 341-42 (1955).

91. These powers notably exemplify the lois du services publics described above. 
ments of the contract, however, can never be unilaterally modified). This may involve additional costs;

- Finally, the Administration may terminate the contract before its normal term without any fault from the private party.

\section{c. Situation of the Private Contractor}

The main right of the private party firm to the delegation is financial, i.e. it must be paid for the implementation of the public service. As a general principle, private actors must not endanger the public interest and related public services: they have less power than public authorities.

Nevertheless, there are a few guarantees because the powers of public authorities are not absolute. The administrative courts exercise strict judicial review. The conventionally acquired rights and even the economic interests of the private contractor are also taken into account. ${ }^{92}$ That is why in every situation in which the contract has been modified, and even without any fault from the public authority, the private actor has a right to financial compensation. ${ }^{93}$

Two other related theories created by the Council of State exemplify the importance of the indemnification of the contractor. An abnormal and unforeseen disturbance of the contractual equilibrium arises in these two situations. The disruption results either from the public entity party to the contract (théorie du fait du prince), or from events external to both contracting parties (théorie de l'imprévision). The first theory allows a full compensation for the loss incurred whereas the second divides the loss between both parties so as to re-establish the altered financial equilibrium. ${ }^{94}$

\section{Relations with Other Private Parties}

Given the delegation to the private sector, private law generally applies in the relationships between the private actor and the users of the public service, its employees, and its contractual relations with third parties. ${ }^{95}$ In such situations, the most relevant French characteristic lies in the protection of rights granted to employees and users of such public services.

This protection represents one of the main problems with privatization in the United States because the Constitution guarantees individual rights only from

92. Langrod, supra note 90 , at 343.

93. CE, Mar. 11, 1910, Compagnie générale française des Tramways Rec. Lebon, 216.

94. Chapus, supra note 26, at 1209-15.

95. However, administrative law may sometimes apply in such situations. See sources cited supra note 75. 
governmental action. ${ }^{96}$ For example, the Supreme Court limited the potential reach of the due process clause in the Civil Rights Cases when it held unconstitutional a federal statute that forbade discrimination in private settings. ${ }^{97}$ So the litigant must prove that he is challenging a government action, whether state or federal. This is what the problem of state action is about. ${ }^{98}$

As Harold Sullivan noted in practical terms, "[e]ven when government remains responsible through both funding and regulation for provision of a service, if production is in private hands, an employee can be dismissed, and a citizen can be denied service without the minimal constitutional safeguards that would apply if production had been in public hands." ation in analyzing the rights of employees is whether the employment at issue is public or private." ${ }^{100}$ For example, whereas public employees' freedom of expression is protected by the First Amendment, private sector employees have fewer rights to express their opinions. ${ }^{101}$

Facing such problems, U.S. scholars often try to solve the dilemma by using a comparative perspective. ${ }^{102}$ The French experience, although useful, usually is forgotten.

Rights in France are protected against private powers when privatization occurs. This is not a specific protection of administrative law, but the consequence of the French protection of rights. In France the object of the Constitution is much larger than the attribution and the definition of rights. This attribution is a political function that is exercised by the legislative power, which protects both public and private persons. It implies that a third party effect doctrine seems useless. ${ }^{103}$

In practical terms, users of public services have rights (particularly equality) against the private contractor because of the public service principles described

96. See Laurence H. Tribe, American Constitutional Law $§ 18-1$ (2d ed. 1988).

97. Civil Rights Cases, 109 U.S. 3 (1883).

98. See sources cited supra note 18.

99. Harold J. Sullivan, Privatization of Public Services: A Growing Threat to Constitutional Rights, 47 Pub. Admin. Rev. 461, 464 (1987).

100. Mark A. Rothstein et al., Employment Law 408 ( 2 d ed. 1999).

101. See Patrick Morvan, An European Look to the Workers' Freedom of Speech in American Law: 'Seeking Desperately' The First Amendment in the Workplace, available at http://patrickmorvan.overblog.com/article-7349508.html.

102. See, e.g., Mark Tushnet, The Issue of State Action/Horizontal Effect in Comparative Constitutional Law, 1 INT'L J. Const. L. 79 (2003) (comparing findings within English-speaking countries and Germany).

103. See Michel Troper, Who Needs a Third Party Effect Doctrine-The Case of France, in THE Constitution in Private Relations: Expanding Constitutionalism 115, 128 (Andras Sajo \&x Renata Utiz eds., 2005). 
above. ${ }^{104}$ Along the same lines, all employees working in public services have important rights. ${ }^{105}$ In particular, when contracting out to private hands occurs, private labor law protects the freedom of expression ${ }^{106}$ and due process for all disciplinary sanctions. ${ }^{107}$

\section{Conclusion}

The French model represents a specific way for protecting public law values, both by limiting the scope of privatization and by applying a legal regime within which public law norms play an active role. This model is specific to France and this article has not argued that it can or should be applied in the United States. Nevertheless, it can enrich American debates.

The opposite is also true. Both globalization and European construction induce major changes in the role of the state. In the last decades, private parties have been increasingly involved in public activities. ${ }^{108}$ Consequently, one may wonder whether the French specificity will live or die. ${ }^{109}$

The final issue remains how far a model can evolve without losing its spirit. A U.S. comparison could be a good way for French scholars to determine and understand the strengths and weaknesses of their system.

104. The lois du service public apply to all public services whether publicly or privately provided. See supra Part II.A.

105. There are potentially three categories of employees working in public service: the permanent civil servants whose status is governed by specific public law norms (les fonctionnaires), the civil servants with a contractual employment ruled by private law (as is mostly the case when public service is provided by a private contractor), and other civil servants whose status is governed by public law norms but less protective than the status of the fonctionnaires. Their situation is therefore problematic, especially in social matters. In order to harmonize the protection, some statutes have been enacted to grant protections to such people. The Council of State has also applied to this latter category what is referred to as "general principles of law" (principes généraux du droit). For example, the Council held that the general principles that derive from the Labour code (for contracts ruled by private law) and the status of the fonctionnaires must be extended to all employees providing a public service. See $\mathrm{CE}$ Sect., Apr. 23, 1982, Ville de Toulouse c/Mme Aragnou Rec. 152 (for a minimum guaranteed wage); CE Ass., June 8, 1973, Dame Peynet Rec. 406 (for the protection of the pregnant).

106. C. Trav. 120-2; C. Trav. 122-45.

107. C. Trav. 122-41.

108. See supra Part I.B. (regarding, for example, the increasing role of private actors in prisons and policing activities).

109. See, e.g., Jean-Marie Pontier, L'intérêt Général Existe-t-il Encore?, 35 Rec. Dalloz 327 (1998). 